\title{
International Interinstitutional PhD Program in Nursing: a successful experience between Brazil and Chile
}

\section{Doutorado Interinstitucional Internacional em Enfermagem: experiência exitosa entre Brasil e Chile \\ Doctorado Interinstitucional Internacional en Enfermería: experiencia exitosa entre Brasil y Chile}

\footnotetext{
${ }^{1}$ Universidade de São Paulo, Escola de Enfermagem, Departamento de Enfermagem Medico-Cirúrgica, São Paulo, SP, Brazil.

2 Pontificia Universidad Católica de Chile, Escola de Enfermagem, Departamento de Salud del Adulto y Senescente, Santiago, Chile.

${ }^{3}$ Universidade de São Paulo, Escola de Enfermagem, Departamento de Enfermagem em Saúde Coletiva, São Paulo, SP, Brazil.
}

How to cite this article:

Pimenta CAM, Lagunas LF, Bertolozzi MR, Secoli SR. International Interinstitutional PhD Program in Nursing: a successful experience between Brazil and Chile. Rev Esc Enferm USP. 2019;53:e03467. DOI: http://dx.doi.org/10.1590/S1980-220X2019ed0103467

Collaboration between universities is a fundamental strategy for the training and specialization of researchers and the development of science, which requires boldness and a climate of trust and mutual support.

The School of Nursing of the University of São Paulo (EEUSP), in accordance with this vision, acceded to the request of the School of Nursing of the Pontifical Catholic University of Chile (EEPUC) to take on the responsibility, at the $\mathrm{PhD}$ level, of training Chilean nurses. From this initiative stemmed the proposal of the International Interinstitutional PhD Program (DINTER International EEUSP/ PUC-Chile).

This pioneer proposal in Brazil and USP led the Coordination for the Improvement of Higher Education Personnel (CAPES - Coordenação de Aperfeiçoamento de Pessoal do Ensino Superior) to propose Notice 013/2011 regarding DINTER International. DINTER International EEUSP/EEPUC-Chile was launched at EEUSP, in 2012, for the following purposes: build knowledge at different levels of health care based on systematic studies and scientific investigations; train human resources capable of detecting problems and providing scientifically-based solutions; form a critical mass of creative and innovative professionals; and create an internationalization environment that would promote multicenter, collaborative and networking-based research.

DINTER International EEUSP/EEPUC-Chile was coordinated by the Graduate Studies Program in Adult Health Nursing of the School of Nursing of USP (PROESA), with the participation of three programs from the Graduate Studies Program in Nursing (PPGE) and the Graduate Studies Program in Nursing Management (PPGEn). The proposal involved the cooperation of professors and the disciplines of adult health, women's health, collective health and nursing management.

There were a variety of challenges in developing a DINTER International. However, cooperation and mutual trust enabled the difficulties of such a pioneer initiative to be overcome. 
Communication, due to the differences in language, culture and distance required organization, versatility, tolerance, and perseverance in the actions of professors, students and administrative staff. The students took proficiency tests in Portuguese and English. The academic activities were carried out in Brazil and Chile, and the theses were written in Spanish. The program abided by the rules for USP Graduate Studies Programs, in order to maintain the quality of the education.

DINTER International did not receive financial support from CAPES, and the costs of the project were the sole responsibility of the foreign institutions of higher learning and, also of the students. Professors, supervisors, and employees from USP and EEPUC were not specifically compensated for this activity. However, USP provided all the necessary physical and material infrastructure and human resources for the activities in Brazil.

The challenges were overcome and highly important benefits were generated. Nine $\mathrm{PhD}$ students received their degrees in sciences, and the knowledge produced through the theses was disseminated through scientific articles and papers presented at relevant national and international events. DINTER will enable Chilean nursing to achieve one of the objectives of the EEPUC, which is to organize an independent $\mathrm{PhD}$ program and boost the production of scientifically significant studies for health and nursing. Such products will undoubtedly help strengthen nursing research in Chile and, also, in the Latin America.

The theses of DINTER International addressed challenging topics in nursing care, such as the limits and potential of nursing training for dealing with violence against children and adolescents, early abandonment of breastfeeding by adolescents, promotion of early father-child contact at the time of birth, and men's experiences as new fathers ${ }^{(1-4)}$.

Urgent demands in relation to interpersonal competencies of health professionals were examined in studies that built a scale for measuring the perception of patients regarding professional behaviors that express human warmth. There were also studies on social interaction and relationships with leadership, work climate and satisfaction of members of interprofessional teams in the hospital context ${ }^{(5-7)}$.

Life protective or threatening factors and complications during the transport of victims to intensive care units, as well as quality of life, were studied in the context of women with pelvic organ prolapse and in the exercise of teaching ${ }^{(8-9)}$.

This successful experience served as a model for CAPES to create the DINTER International program and as a model and inspiration for the creation of various DINTER in Brazil with different Latin American countries, including other fields of knowledge. This investment could also serve as a model for creating projects to unify the training of professionals for research in Latin America, which has significant inequalities in terms of requirements and products for obtaining a $\mathrm{PhD}$ in sciences. The strengthening of research in regional nursing will help improve the health care given to the population of South America.

DINTER EEUSP/PUC-Chile worked in partnership with two universities of excellence and benefited from higher international cooperation. PUC-Chile has maintained its position as the first or second best university in Latin America. The formal and extended partnership with this institution of higher education enabled professors, students and other institutions of higher education to strengthen the experience of working in international groups and share pedagogical experiences, methods and research frameworks, in addition to exercising cultural sensitivity, a value that is pursued in modern societies.

With respect to products, the proposal was designed to form a research network between the institutions of higher education, with the possibility of expansion to other such institutions in Brazil and Latin America, in addition to the project of joint doctorates with PUC-Chile to be implemented in the future. The first major offshoot of the DINTER International experience for EEUSP was in 2017, the signing of a cooperation agreement between EEUSP and the School of Nursing of the University of Los Andes (Chile) for $\mathrm{PhD}$ programs, following the same model and objectives adopted in DINTER EEUSP/EEPUC-Chile, attesting to the excellence of this experience.

We would like to thank all those who participated, gave their support and authorized this initiative: students, professors, administrative staff, program coordinators, EEUSP, EEPUC-Chile, the International Cooperation Agency, the Dean for Graduate Studies of USP and CAPES.

\section{REFERENCES}

1. Martínez-Santana DC. Limites e potencialidades da formação profissional para o enfrentamento da violência contra crianças e adolescentes [tese doutorado]. São Paulo: Universidade de São Paulo, Escola de Enfermagem; 2018.

2. Núñez-Hernández MI. Abandono do aleitamento materno exclusivo em mães adolescentes: estudo de coorte [tese doutorado]. São Paulo: Universidade de São Paulo, Escola de Enfermagem; 2017. 
3. Uribe-Torres C. Pesquisa-ação: intervenção educativa para a promoção do contato precoce pai-filho no contexto do nascimento [tese doutorado]. São Paulo: Universidade de São Paulo, Escola de Enfermagem; 2017.

4. Márquez-Doren FA. Significados y participación social del hombre chileno al transformarse en padre por primera vez [tese doutorado]. São Paulo: Universidade de São Paulo, Escola de Enfermagem; 2016.

5. Quiroz-Espinoza PA. Satisfacción en equipos interprofesionales: relaciones interpersonales, liderazgo transformacional y clima de equipos en un hospital de Santiago, Chile: un estudio de métodos mixtos [tese doutorado]. São Paulo: Universidade de São Paulo, Escola de Enfermagem; 2016.

6. Giordano-Parra DR. Qualidade de vida: percepção de enfermeiros docentes [tese doutorado]. São Paulo: Universidade de São Paulo, Escola de Enfermagem; 2017.

7. Lagos-Sánchez, Z. Escala Calidez de Enfermagem (ECAE): construção e validação [tese doutorado]. São Paulo: Universidade de São Paulo, Escola de Enfermagem; 2017.

8. Carrillo-Berrera MJ. Deterioração fisiopatológico e mortalidade de pacientes críticos adultos submetidos a traslado inter hospitalar por unidades móveis do Serviço de Atenção Médica de Urgência da área metropolitana, Santiago de Chile [tese doutorado]. São Paulo: Universidade de São Paulo, Escola de Enfermagem; 2017.

9. Flores Espinoza CC. Qualidade de vida das mulheres com prolapso de órgão pélvico após de tratamento cirúrgico [tese doutorado]. São Paulo: Universidade de São Paulo, Escola de Enfermagem; 2017. 